\title{
Mental illness and violent behavior: the role of dissociation
}

\author{
Aliya R. Webermann ${ }^{1 *}$ and Bethany L. Brand ${ }^{2}$
}

\begin{abstract}
Background: The role of mental illness in violent crime is elusive, and there are harmful stereotypes that mentally ill people are frequently violent criminals. Studies find greater psychopathology among violent offenders, especially convicted homicide offenders, and higher rates of violence perpetration and victimization among those with mental illness. Emotion dysregulation may be one way in which mental illness contributes to violent and/or criminal behavior. Although there are many stereotyped portrayals of individuals with dissociative disorders (DDs) being violent, the link between DDs and crime is rarely researched.

Methods: We reviewed the extant literature on DDs and violence and found it is limited to case study reviews. The present study addresses this gap through assessing 6-month criminal justice involvement among 173 individuals with DDs currently in treatment. We investigated whether their criminal behavior is predicted by patient self-reported dissociative, posttraumatic stress disorder and emotion dysregulation symptoms, as well as clinician-reprted depressive disorders and substance use disorder.

Results: Past 6 month criminal justice involvement was notably low: 13\% of the patients reported general police contact and 5\% reported involvement in a court case, although either of these could have involved the DD individual as a witness, victim or criminal. Only 3.6\% were recent criminal witnesses, $3 \%$ reported having been charged with an offense, $1.8 \%$ were fined, and $0.6 \%$ were incarcerated in the past 6 months. No convictions or probations in the prior 6 months were reported. None of the symptoms reliably predicted recent criminal behavior.
\end{abstract}

Conclusions: In a representative sample of individuals with DDs, recent criminal justice involvement was low, and symptomatology did not predict criminality. We discuss the implications of these findings and future directions for research.

Keywords: Crime, Criminal behavior, Dissociation, Dissociative disorders, Trauma, Emotion dysregulation, PTSD, Violent crime

\section{Background}

Stereotypes abound in the media regarding violent behavior and crimes among those with mental illness. One need not look further than popular crime television shows, the latest blockbuster film or news stories on perpetrators of atrocities such as school shootings or terrorist attacks. Researchers have worked to unpack the complex question of what role mental illness plays in violence, if any, especially in light of mass shootings in the United States at Sandy Hook Elementary, Virginia Tech University and Pulse Nightclub, among

\footnotetext{
* Correspondence: aliyaw1@umbc.edu

'University of Maryland Baltimore County, 1000 Hilltop Circle, Math/

Psychology Building Rm. 312, Baltimore County, Baltimore, MD 21250, USA

Full list of author information is available at the end of the article
}

others. Researchers generally agree that there is some relationship between mental illness and the risk for violence, such that mental illness increases the risk for violence perpetration as well as victimization, but there is less consensus on the specific psychopathology and symptoms that contribute to violence.

\section{A brief literature review on mental illness and violent behavior}

Stereotypes about mental illness and violence are common among the general public. Link, Phelan, Bresnahan, Stueve and Pescosolido [1] presented a large sample $(N=1444)$ with vignettes of people with mental illness, in which no violent behavior or thoughts were 
described, and inquired how likely it was that the "patient" would be violent. Many participants believed it likely that the hypothetical mentally ill individual would perpetrate violence: $17 \%$ of respondents endorsed violence as likely among those with minor interpersonal problems, and 33\% and 61\% thought violence was likely among people with major depression or schizophrenia, respectively. Individuals with mental illness are frequently aware of others' negative perceptions of them, which can worsen isolation, negative affect and treatment adherence [2, 3].

Individuals with psychological disorders that are highly stigmatized and misunderstood, such as schizophrenia, borderline personality disorder (BPD) and dissociative identity disorder (DID), often face harmful and inaccurate stereotypes which portray them as dangerous and untreatable menaces who require psychiatric or forensic institutionalization. However, as we will review in this study, it is a myth that individuals with DID are the most likely patients in the mental health system to be violent. Various methodologies have been used to study the link between mental illness and violence including: reporting on the prevalence of mental illness among convicted violent offenders, typically homicide defendants; examining violent behavior and crime among clinical populations; and assessing prevalence of violent behavior and crime among those with mental illness in the general population (see Tables 1, 2, 3, 4 and 5 below for the results of studies utilizing each of these methodologies). Many studies examine only violence perpetration, but some examine victimization as well [4-6] (Table 1).

In research on the prevalence of mental illness among violent offenders, multiple studies have found the highest rates of violence among individuals with substance use disorders, rather than schizophrenia, BPD and other psychotic disorders [7-11] (Tables 2 and 3). Rates of substance use disorders (including alcohol use disorders and illicit substance use disorders) among self-reported violent offenders range from 20 to $42 \%[7,11,12]$ (Table 2). Rates of substance use disorders among convicted homicide offenders are lower but still noteworthy, ranging from 1 to $20 \%[8,9,13,14]$ (Table 3).

Other studies have approached the question of how mental illness intersects with violence through examining rates of violent behavior among clinical populations. These studies tend to focus on severe/serious mental illness (SMI), that is, disorders which cause or are associated with serious functional impairment or limitations on major life activities [15]. The majority of studies on violent behavior among SMI patients focus on schizophrenia, although some also include other SMIs such as bipolar disorder and antisocial personality disorder (Table 4). Studies on violent behavior and homicide among individuals with schizophrenia indicate these individuals are at increased risk for both violence perpetration and victimization, but that violence is often predicted by comorbid substance use, medication noncompliance and a recent history of being assaulted [16-18]. Studies on violent behavior among individuals with BPD indicate that emotion dysregulation is a longitudinal mediator of violent behavior and may be a primary mechanism that increases risk for violence in this population $[19,20]$. The complex DDs, including DID, have been conceptualized as disorders of emotional dysregulation and are often highly comorbid with BPD [21]. The association of emotion dysregulation with violence in DDs should be further examined.

\section{Dissociative disorders and violent behavior}

Notably missing from almost all studies on the intersection of mental illness and violent crime are individuals with dissociative disorders (DDs), including DID and DD not otherwise specified (DDNOS in DSM-IV)/other

Table 1 Victimization among DD and mixed clinical populations

\begin{tabular}{|c|c|c|c|c|c|c|c|c|}
\hline Study & Data source and timeframe & $N$ & Homicide & $\begin{array}{l}\text { Severe } \\
\text { assault }\end{array}$ & $\begin{array}{l}\text { Any } \\
\text { violent crime }\end{array}$ & $\begin{array}{l}\text { IPV } \\
\text { (physical/sexual) }\end{array}$ & $\begin{array}{l}\text { Sexual } \\
\text { Assault }\end{array}$ & $\begin{array}{l}\text { Diagnoses } \\
\text { represented in study }\end{array}$ \\
\hline \multirow[t]{4}{*}{$\begin{array}{l}\text { Crisanti et al. } \\
(2014)[4]^{b}\end{array}$} & \multirow{4}{*}{$\begin{array}{l}\text { Adult outpatients at community } \\
\text { mental health centers, Hawaii, } \\
\text { US, 6-month timeframe }\end{array}$} & \multirow[t]{4}{*}{2209} & \multirow[t]{4}{*}{ N/A } & \multirow[t]{4}{*}{$12.3 \%$} & \multirow[t]{4}{*}{ N/A } & \multirow[t]{4}{*}{$\mathrm{N} / \mathrm{A}$} & \multirow{4}{*}{$\begin{array}{l}\text { Grouped } \\
\text { w/severe } \\
\text { violence }\end{array}$} & $\begin{array}{l}\text { Other psychotic disorder } \\
(26.4 \%)\end{array}$ \\
\hline & & & & & & & & $\begin{array}{l}\text { Other severe mental } \\
\text { health disorders (18.9\%) }\end{array}$ \\
\hline & & & & & & & & Mood disorders (11.8\%) \\
\hline & & & & & & & & Schizophrenia (10.1\%) \\
\hline $\begin{array}{l}\text { Teplin et al. (2005) } \\
{[5]^{]^{a}}}\end{array}$ & $\begin{array}{l}\text { Adult partial day outpatient, } \\
\text { full outpatient and inpatient, } \\
\text { Illinois, US, 12-month timeframe }\end{array}$ & 936 & N/A & N/A & $25.32 \%$ & N/A & $2.64 \%$ & $\begin{array}{l}\text { Psychotic/major } \\
\text { affective disorder (100\%) }\end{array}$ \\
\hline \multirow{2}{*}{$\begin{array}{l}\text { Webermann et al. } \\
(2014)[6]^{b}\end{array}$} & \multirow{2}{*}{$\begin{array}{l}\text { 94\% female outpatients } \\
\text { with DID, adult lifetime }\end{array}$} & \multirow[t]{2}{*}{275} & \multirow[t]{2}{*}{ N/A } & \multirow[t]{2}{*}{ N/A } & \multirow[t]{2}{*}{ N/A } & \multirow[t]{2}{*}{ 26.1\% (physical) } & \multirow[t]{2}{*}{ N/A } & DID 98\% \\
\hline & & & & & & & & DDNOS 2\% \\
\hline
\end{tabular}

aself-report

${ }^{\mathrm{b} C l i n i c i a n}$ reports 
Table 2 Violent behavior, homicide and psychopathology among general populations

\begin{tabular}{|c|c|c|c|c|c|c|c|}
\hline Study & Data source and timeframe & $N$ & Homicide & $\begin{array}{l}\text { Severe } \\
\text { assault }\end{array}$ & $\begin{array}{l}\text { Any violent } \\
\text { crime }\end{array}$ & Sexual assault & $\begin{array}{l}\text { Diagnoses represented } \\
\text { in study (among only } \\
\text { perpetrators when possible) }\end{array}$ \\
\hline \multirow{9}{*}{$\begin{array}{l}\text { Coker et al. } \\
(2014)[12]^{a / b}\end{array}$} & \multirow{9}{*}{$\begin{array}{l}\text { National Comorbidity } \\
\text { Survey-Adolescent Supplement, } \\
\text { US (ages 13-17), 2001-2004, } \\
\text { lifetime timeframe }\end{array}$} & \multirow[t]{9}{*}{10,123} & \multirow[t]{9}{*}{$\mathrm{N} / \mathrm{A}$} & \multirow[t]{9}{*}{$\mathrm{N} / \mathrm{A}$} & \multirow{9}{*}{$\begin{array}{l}1.7 \% \text { a/b } \\
\text { (same } \% \text { for both } \\
\text { arrest record } \\
\text { and self-report) }\end{array}$} & \multirow[t]{9}{*}{ N/A } & Conduct disorder (20.42\%) \\
\hline & & & & & & & $\begin{array}{l}\text { Substance use disorder } \\
(19.58 \%)\end{array}$ \\
\hline & & & & & & & Mood disorder (12.51\%) \\
\hline & & & & & & & ADHD (6.8\%) \\
\hline & & & & & & & $\begin{array}{l}\text { Oppositional defiant } \\
\text { disorder (4.54\%) }\end{array}$ \\
\hline & & & & & & & $\begin{array}{l}\text { Intermittent explosive } \\
\text { disorder (4.29\%) }\end{array}$ \\
\hline & & & & & & & Eating disorder (3.43\%) \\
\hline & & & & & & & PTSD (2.92\%) \\
\hline & & & & & & & No diagnosis (0.37\%) \\
\hline \multirow{7}{*}{$\begin{array}{l}\text { Elbogen \& } \\
\text { Johnson (2009) } \\
{[7]^{\mathrm{b}}}\end{array}$} & \multirow{7}{*}{$\begin{array}{l}\text { National Epidemiologic Survey } \\
\text { on Alcohol and Related Conditions } \\
\text { (NESARC), US, 2001-2003, } \\
\text { lifetime timeframe }\end{array}$} & \multirow[t]{7}{*}{34,653} & \multirow[t]{7}{*}{ N/A } & \multirow[t]{7}{*}{$6.78 \%$} & \multirow[t]{7}{*}{$17.68 \%$} & \multirow[t]{7}{*}{$\begin{array}{l}\text { Grouped w/ } \\
\text { severe violence }\end{array}$} & $\begin{array}{l}\text { Substance use disorder } \\
\text { only }(21.41 \%)\end{array}$ \\
\hline & & & & & & & $\begin{array}{l}\text { Mood disorder only } \\
(10.47 \%)\end{array}$ \\
\hline & & & & & & & $\begin{array}{l}\text { Mood disorder + substance } \\
\text { abuse (8.94\%) }\end{array}$ \\
\hline & & & & & & & $\begin{array}{l}\text { Schizophrenia + substance } \\
\text { abuse }(0.46 \%)\end{array}$ \\
\hline & & & & & & & Schizophrenia only (0.40\%) \\
\hline & & & & & & & No diagnosis (58.32\%) \\
\hline & & & & & & & $\begin{array}{l}\text { Diagnoses represent total } \\
N \text {, not just offenders }\end{array}$ \\
\hline $\begin{array}{l}\text { Federal Bureau } \\
\text { of Investigations } \\
(\text { FBI) }\end{array}$ & $\begin{array}{l}\text { Uniform Crime Reporting (UCR) } \\
\text { Program, FBI, 2014, US, } 1 \text { year }\end{array}$ & $\begin{array}{l}318.9 \\
\text { million }\end{array}$ & $.004 \%$ & $0.23 \%$ & $0.37 \%$ & $.03 \%$ & N/A \\
\hline \multirow[t]{5}{*}{$\begin{array}{l}\text { Swanson et al. } \\
(1990)[11]^{b}\end{array}$} & \multirow{5}{*}{$\begin{array}{l}\text { Epidemiological Catchment } \\
\text { Area survey, National Institute } \\
\text { of Mental Health, US, } \\
1 \text { year timeframe }\end{array}$} & \multirow[t]{5}{*}{10,059} & \multirow[t]{5}{*}{ N/A } & & \multirow[t]{5}{*}{$3.66 \%$} & \multirow[t]{5}{*}{ N/A } & $\begin{array}{l}\text { Substance use disorder } \\
(41.64 \%)\end{array}$ \\
\hline & & & & & & & Anxiety disorders (20.13\%) \\
\hline & & & & & & & Mood disorder (9.37\%) \\
\hline & & & & & & & $\begin{array}{l}\text { Schizophrenia/ } \\
\text { schizophreniform disorder } \\
(3.92 \%)\end{array}$ \\
\hline & & & & & & & No diagnosis (44.5\%) \\
\hline
\end{tabular}

specified DD (OSDD in DSM-5). This is true of mixed clinical population studies [22-25], studies on violence and mental illness in the general population $[7,11,12$, 26], as well as forensic studies of convicted violent offenders $[8,9,13,14,27]$. Although DID is missing from almost all the research on mental illness and violence, it gets an inordinate amount of focus in films about mental illness, particularly those in the horror and thriller genres such as Split, Psycho, Fight Club or Secret Window which portray people with dissociative self-states as prone to violence including homicide, or within comedies that poke fun at the "outlandishness" of dissociative self-states, such as Me, Myself and Irene. Given the paucity of research on violent behavior among individuals with DDs, coupled with the saturation of stereotypic portrayals of DDs in the media, misunderstanding abounds regarding what role dissociation plays in violent behavior, if any.

A few studies have examined dissociative symptoms, rather than DDs, as a predictor of violent interpersonal behavior within mixed clinical populations (Table 4). They typically focus on trait dissociation, that is, chronic and enduring dissociative experiences across multiple contexts [28], compared to state dissociation, e.g., 
Table 3 Psychopathology among convicted homicide offenders

\begin{tabular}{|c|c|c|c|c|}
\hline Study & Data source and timeframe & Population & $N$ & Diagnoses represented in study \\
\hline \multirow[t]{12}{*}{ Fazel \& Grann (2004) [8] } & \multirow{12}{*}{$\begin{array}{l}\text { Sweden state crime register } \\
\text { 1988-2011, 14-year timeframe }\end{array}$} & \multirow{12}{*}{$\begin{array}{l}\text { Convicted homicide offenders, } \\
91.7 \% \text { male }\end{array}$} & \multirow[t]{12}{*}{2005} & Substance use disorder (19.7\%) \\
\hline & & & & Personality disorder (11.3\%) \\
\hline & & & & Schizophrenia (8.9\%) \\
\hline & & & & Other psychotic disorder (6.5\%) \\
\hline & & & & Mood disorder (4.8\%) \\
\hline & & & & Anxiety disorder (1.4\%) \\
\hline & & & & Adjustment disorder (2.8\%) \\
\hline & & & & $\begin{array}{l}\text { Drug-induced or organic } \\
\text { psychosis }(2.4 \%)\end{array}$ \\
\hline & & & & Intellectual disability (0.6\%) \\
\hline & & & & PTSD (0.5\%) \\
\hline & & & & Other axis I disorder (11.9\%) \\
\hline & & & & No diagnosis (8\%) \\
\hline \multirow[t]{5}{*}{ Flynn et al. (2011) [9] ${ }^{a}$} & \multirow{5}{*}{$\begin{array}{l}\text { UK and Wales National Confidential } \\
\text { Inquiry into Suicide and Homicide } \\
\text { by People with Mental Illness (NCI), } \\
\text { 1997-2004, 8-year timeframe }\end{array}$} & \multirow{5}{*}{$\begin{array}{l}\text { Convicted homicide offenders, } \\
90 \% \text { male }\end{array}$} & \multirow[t]{5}{*}{4752} & Substance use disorder (8.22\%) \\
\hline & & & & Personality disorder (6.71\%) \\
\hline & & & & Mood disorder (6.32\%) \\
\hline & & & & Schizophrenia (5.8\%) \\
\hline & & & & No diagnosis (68.33\%) \\
\hline \multirow[t]{5}{*}{ Rodway et al. (2014) [13] a } & \multirow{5}{*}{$\begin{array}{l}\text { UK and Wales National Confidential } \\
\text { Inquiry into Suicide and Homicide } \\
\text { by People with Mental IIIness (NCl), } \\
\text { 2003-2005, 3-year timeframe }\end{array}$} & \multirow[t]{5}{*}{$\begin{array}{l}\text { Convicted homicide offenders, } \\
90 \% \text { male }\end{array}$} & \multirow[t]{5}{*}{28} & $\begin{array}{l}\text { Schizophrenia or delusional } \\
\text { disorder (50\%) }\end{array}$ \\
\hline & & & & Personality disorder (21\%) \\
\hline & & & & Substance use disorder (15\%) \\
\hline & & & & Mood disorder (4\%) \\
\hline & & & & No diagnosis (10\%) \\
\hline \multirow[t]{8}{*}{ Simpson et al. (2004) [14] ${ }^{a}$} & \multirow{8}{*}{$\begin{array}{l}\text { Homicide Monitoring Database } \\
\text { of the New Zealand Police/Law } \\
\text { Enforcement System, New Zealand, } \\
\text { 1970-2000, 30-year timeframe }\end{array}$} & \multirow{8}{*}{$\begin{array}{l}\text { Convicted homicide offenders, } \\
68 \% \text { male }\end{array}$} & \multirow[t]{8}{*}{1498} & Schizophrenia (3.67\%) \\
\hline & & & & Other psychotic disorder (1.27\%) \\
\hline & & & & Mood disorder (1.2\%) \\
\hline & & & & Personality disorder (0.73\%) \\
\hline & & & & Substance use disorder (0.67\%) \\
\hline & & & & Neurocognitive disorder (0.60\%) \\
\hline & & & & Intellectual disability (0.60\%) \\
\hline & & & & No diagnosis (91.3\%) \\
\hline \multirow[t]{9}{*}{ Wilcox (1985) [27] $]^{\mathrm{a}}$} & \multirow{9}{*}{$\begin{array}{l}\text { Contra Costa County, California } \\
\text { Coroner's Office (US), 1978-1980, } \\
\text { 3-year timeframe }\end{array}$} & \multirow[t]{9}{*}{$\begin{array}{l}\text { Convicted homicide offenders, } \\
\text { gender demographics N/A }\end{array}$} & \multirow[t]{9}{*}{71} & $\begin{array}{l}\text { Antisocial personality disorder } \\
(32.4 \%)\end{array}$ \\
\hline & & & & Substance use disorder (19.7\%) \\
\hline & & & & Schizophrenia (9.85\%) \\
\hline & & & & Neurocognitive disorder (2.82\%) \\
\hline & & & & Adjustment disorder (1.41\%) \\
\hline & & & & $\begin{array}{l}\text { Substance-induced psychotic } \\
\text { disorder }(1.41 \%)\end{array}$ \\
\hline & & & & $\begin{array}{l}\text { Substance-induced psychotic } \\
\text { disorder }(1.41 \%)\end{array}$ \\
\hline & & & & $\begin{array}{l}\text { Other personality disorder } \\
(1.41 \%)\end{array}$ \\
\hline & & & & No diagnosis (31\%) \\
\hline
\end{tabular}


Table 4 Violent behavior and homicide among mixed clinical populations

\begin{tabular}{|c|c|c|c|c|c|c|c|}
\hline Study & $\begin{array}{l}\text { Data source and } \\
\text { timeframe }\end{array}$ & $N$ & Homicide & Severe assault & $\begin{array}{l}\text { Any violent } \\
\text { crime }\end{array}$ & $\begin{array}{l}\text { Sexual assault/ } \\
\text { interpersonal violence }\end{array}$ & $\begin{array}{l}\text { Diagnoses represented } \\
\text { in study (among only } \\
\text { perpetrators } \\
\text { when possible) }\end{array}$ \\
\hline \multirow[t]{4}{*}{$\begin{array}{l}\text { Bruce et al. } \\
(2014)[22]^{a / b}\end{array}$} & \multirow{4}{*}{$\begin{array}{l}\text { Biomedical Research } \\
\text { Centre Case Register } \\
\text { Interactive Search } \\
\text { tool, UK, 2009, } \\
\text { lifetime timeframe }\end{array}$} & \multirow[t]{4}{*}{165} & \multirow[t]{4}{*}{$N / A$} & \multirow[t]{4}{*}{$35.2 \%^{b}$} & \multirow[t]{4}{*}{$46.1 \%^{a}$} & \multirow[t]{4}{*}{$\begin{array}{l}\text { Sexual assault grouped } \\
\text { w/severe violence }\end{array}$} & $\begin{array}{l}\text { Schizophrenia } \\
(66.67 \%)\end{array}$ \\
\hline & & & & & & & $\begin{array}{l}\text { Substance use } \\
\text { disorder (35.2\%) }\end{array}$ \\
\hline & & & & & & & $\begin{array}{l}\text { Antisocial personality } \\
\text { disorder }(24.2 \%)\end{array}$ \\
\hline & & & & & & & $\begin{array}{l}\text { Diagnoses represent } \\
\text { total } N \text {, not just } \\
\text { offenders }\end{array}$ \\
\hline $\begin{array}{l}\text { Egeland and } \\
\text { Susman- } \\
\text { Stillman (1996) } \\
{[33]^{c}}\end{array}$ & $\begin{array}{l}\text { Mothers/survivors of } \\
\text { childhood maltreatment, } \\
\text { outpatient }\end{array}$ & 24 & N/A & N/A & N/A & $\begin{array}{l}\text { 58.33\% childhood } \\
\text { maltreatment } \\
\text { (dissociation } \\
\text { significantly higher } \\
\text { among abusive mothers) }\end{array}$ & N/A \\
\hline \multirow{4}{*}{$\begin{array}{l}\text { Hodgins et al. } \\
(2007)[23]^{a / b}\end{array}$} & \multirow{4}{*}{$\begin{array}{l}\text { Adult inpatients in } \\
\text { government mental } \\
\text { health hospital, UK, } \\
\text { lifetime timeframe }\end{array}$} & \multirow[t]{4}{*}{205} & \multirow[t]{4}{*}{ N/A } & \multirow[t]{4}{*}{$33.2 \%^{b}$} & \multirow[t]{4}{*}{$34.1 \%^{\mathrm{a}}$} & \multirow[t]{4}{*}{ N/A } & Schizophrenia (65\%) \\
\hline & & & & & & & $\begin{array}{l}\text { Substance use } \\
\text { disorder (60\%) }\end{array}$ \\
\hline & & & & & & & $\begin{array}{l}\text { Bipolar disorder I or II } \\
(18.5 \%)\end{array}$ \\
\hline & & & & & & & $\begin{array}{l}\text { Schizoaffective } \\
\text { disorder (8.78\%) }\end{array}$ \\
\hline \multirow[t]{4}{*}{$\begin{array}{l}\text { Jordan et al. } \\
(1996)[25]^{b}\end{array}$} & \multirow{4}{*}{$\begin{array}{l}\text { Women entering } \\
\text { prison, US, 6-24 } \\
\text { month timeframe }\end{array}$} & \multirow[t]{4}{*}{805} & & & & & $\begin{array}{l}\text { Substance use } \\
\text { disorder (47.4\%) }\end{array}$ \\
\hline & & & & & & & $\begin{array}{l}\text { Borderline personality } \\
\text { disorder (28\%) }\end{array}$ \\
\hline & & & & & & & $\begin{array}{l}\text { Antisocial personality } \\
\text { disorder (11.9\%) }\end{array}$ \\
\hline & & & & & & & $\begin{array}{l}\text { Major depression } \\
(10.8 \%)\end{array}$ \\
\hline $\begin{array}{l}\text { Kaplan et al. } \\
\text { (1998) [32] }\end{array}$ & $\begin{array}{l}\text { Adult outpatients in } \\
\text { mood disorder clinic, } \\
\text { NY, US, lifetime } \\
\text { timeframe }\end{array}$ & 122 & $0 \%$ & $\begin{array}{l}\% \text { N/A but dissociative } \\
\text { symptoms significantly/ } \\
\text { positively correlated } \\
\text { with assault }\end{array}$ & N/A & N/A & $\begin{array}{l}\text { DES score above } \\
\text { cutoff indicative of } \\
\text { potential DD (29\%) }\end{array}$ \\
\hline \multirow{3}{*}{$\begin{array}{l}\text { Matejkowski } \\
\text { et al. (2008) } \\
{[24]^{\mathrm{a}}}\end{array}$} & \multirow{3}{*}{$\begin{array}{l}\text { Indiana Criminal Justice } \\
\text { Institute (US), 1990-2002, } \\
\text { 12-year timeframe }\end{array}$} & \multirow[t]{3}{*}{95} & \multirow[t]{3}{*}{$100 \%$} & \multirow[t]{3}{*}{$46 \%$} & \multirow[t]{3}{*}{ N/A } & \multirow[t]{3}{*}{$14 \%$} & Mood disorder (74\%) \\
\hline & & & & & & & Schizophrenia (28\%) \\
\hline & & & & & & & $\begin{array}{l}\text { Other psychotic } \\
\text { disorder (15\%) }\end{array}$ \\
\hline $\begin{array}{l}\text { Quimby and } \\
\text { Putnam (1991) } \\
{[31]^{c}}\end{array}$ & $\begin{array}{l}\text { Adult inpatients in state } \\
\text { psychiatric hospital, } \\
\text { Maine, US, } \\
\text { lifetime timeframe }\end{array}$ & 70 & N/A & N/A & N/A & $\begin{array}{l}\% \text { N/A but dissociation } \\
\text { significantly/positively } \\
\text { correlated w/sexual } \\
\text { aggression }\end{array}$ & $\begin{array}{l}\text { DES score above } \\
\text { cutoff indicative of } \\
\text { potential DD }(30 \%)^{\mathrm{e}}\end{array}$ \\
\hline
\end{tabular}

$D D$ dissociative disorder, DID dissociative identity disorder, N/A not applicable (not inquired in the study), DES Dissociative Experiences Scale

${ }^{\text {a }}$ Arrest records

${ }^{\mathrm{b}}$ Self-reports

'Clinician reports

${ }^{\mathrm{d} D E S} \geq 25$

${ }^{\mathrm{e}} \mathrm{DES} \geq 30$

transient, not enduring and time-limited dissociative experiences [29], the latter of which are often anecdotally reported by violent offenders, such as amnesia for a violent episode and violence-related dissociative episodes [30]. Quimby and Putnam [31] found that among adult psychiatric inpatients, trait dissociation was positively correlated with patient sexual aggression via staff reports. Kaplan and colleagues [32] found a positive correlation between trait dissociation and patientreported general aggression among psychiatric outpatients. Dissociation has also been posited to play a role in the intergenerational transmission of domestic 
Table 5 Violent behavior and homicide among DD clinical populations

\begin{tabular}{|c|c|c|c|c|c|c|c|c|c|c|}
\hline Study & Population & $N$ & $\begin{array}{l}\text { Violent/ } \\
\text { homicidal } \\
\text { self-states }\end{array}$ & $\begin{array}{l}\text { Severe } \\
\text { assault }\end{array}$ & $\begin{array}{l}\text { Any violent } \\
\text { behavior }\end{array}$ & Incarceration & $\begin{array}{l}\text { IPV } \\
\text { (physical/ } \\
\text { sexual) }\end{array}$ & $\begin{array}{l}\text { Sexual } \\
\text { assault }\end{array}$ & $\begin{array}{l}\text { Childhood } \\
\text { maltreatment } \\
\text { (physical/sexual) }\end{array}$ & Homicide \\
\hline $\begin{array}{l}\text { Dell \& } \\
\text { Eisenhower } \\
(1990)[34]^{a}\end{array}$ & $\begin{array}{l}\text { Adolescents, } \\
\text { outpatient, } \\
\text { 100\% DID }\end{array}$ & 11 & $64 \%$ & N/A & $55 \%$ & N/A & N/A & N/A & N/A & N/A \\
\hline Kluft (1987) [35] & $\begin{array}{l}\text { Mothers, } \\
\text { outpatient, } \\
\text { 100\% DID }\end{array}$ & 75 & $33.3 \%$ & N/A & N/A & N/A & N/A & N/A & $16 \%$ & N/A \\
\hline $\begin{array}{l}\text { Lewis et al. } \\
(1997)[40]^{\mathrm{a}}\end{array}$ & $\begin{array}{l}92 \% \text { male } \\
\text { incarcerated } \\
\text { homicide defendants, } \\
100 \% \text { DID }\end{array}$ & 12 & N/A & N/A & $100 \%$ & $100 \%$ & N/A & N/A & N/A & $100 \%$ \\
\hline $\begin{array}{l}\text { Loewenstein and } \\
\text { Putnam (1990) } \\
{[36]^{\text {a }}}\end{array}$ & $\begin{array}{l}\text { 100\% male in- } \\
\text { and outpatients, } \\
\text { 100\% DID }\end{array}$ & 21 & $60 \%$ & N/A & $47 \%$ & $47 \%$ & N/A & $13 \%$ & N/A & $19 \%$ \\
\hline $\begin{array}{l}\text { Putnam et al. } \\
(1986)[37]^{\mathrm{a}}\end{array}$ & $\begin{array}{l}92 \% \text { female in- } \\
\text { and outpatients, } \\
100 \% \text { DID }\end{array}$ & 100 & $\begin{array}{l}70 \% \\
(53 \% \text { internally } \\
\text { homicidal) }\end{array}$ & N/A & $29 \%$ & N/A & N/A & $20 \%$ & N/A & $19 \%$ \\
\hline $\begin{array}{l}\text { Ross and Norton } \\
(1989)[38]^{\mathrm{a}}\end{array}$ & $\begin{array}{l}88 \% \text { female in- } \\
\text { and outpatients, } \\
100 \% \text { DID }\end{array}$ & 236 & N/A & N/A & $38.3 \%$ & $38.8 \%$ & N/A & N/A & N/A & N/A \\
\hline $\begin{array}{l}\text { Webermann } \\
\text { et al. (2014) [6] }\end{array}$ & $\begin{array}{l}94 \% \text { female } \\
\text { outpatients with DID }\end{array}$ & 275 & N/A & N/A & N/A & N/A & $3.5 \%$ & $\mathrm{~N} / \mathrm{A}$ & N/A & N/A \\
\hline
\end{tabular}

Timeframe is adult lifetime (except for Dell [1990], which is entire lifespan)

$D D$ dissociative disorder, DID dissociative identity disorder, N/A not applicable (not inquired in the study)

${ }^{a}$ Clinician reports

violence: grouping young mothers who were survivors of childhood maltreatment based on whether or not they abused their own children, Egeland and SusmanStillman [33] found significantly greater trait dissociation among mothers who were abusive as compared to those who were not.

A number of case study reviews, conducted nearly three decades ago, reported high rates of violent behavior among patients with DID, according to reports by their treating clinicians [34-38] (Table 5). These studies were typically conducted with small samples derived from the authoring clinician's case load, relied on clinician reports rather than patient self-report, utilized adult lifetime reporting timeframes rather than specified time frames (the latter is more typical of current studies on violence and mental illness), and did not attempt to objectively verify violent behavior through criminal records or other official documentation. Many studies inquired about DID patients' violent and/or homicidal dissociative self-states. ${ }^{1}$ Therapists reported that between 33 and $70 \%$ of DID patients had violent selfstates [34-37]. At times, aggressive self-states within individuals with DID threaten other self-states, which some patients perceive to be internalized homicidal ideation and/or threats, but if carried out, would result in suicide and not homicide. Some of the studies reviewed above did not distinguish violent self-states who were violent towards the individual themselves versus those who were externally violent toward others [34-36]. Putnam and colleagues [37] make the distinction that while $70 \%$ of those with DID had violent or homicidal self-states, $53 \%$ of the aggressive self-states were "internally homicidal," that is, with homicidal ideation toward another self-state. Some DID patients may misperceive these internally aggressive self-states as external violent people, rather than the patient being self-destructive or suicidal [39]. Putnam and colleagues [37] describe internalized homicidal behavior as occurring among 53\% of their 100 DID patient sample. Some DID patients may also experience flashbacks of past violence perpetrated by another person against them and mistakenly believe they are perpetrating violence against someone else when in fact they are experiencing an intrusive recollection of the past [39].

Within these aforementioned case studies, clinicians reported that $38-55 \%$ of their DID patients had a history of any violent behavior [34, 36-38]. Ross and Norton [38] reported that of 236 DID patients, $29 \%$ of the males and $10 \%$ of females reported being convicted of a crime, and the same percentage reported a history of incarceration. While the type of conviction and reason for incarceration were not specified, Ross and Norton [38] describe more antisocial behavior among men than women. Loewenstein and Putnam [36] and Putnam and colleagues [37] report high rates of sexual assault perpetration among their DID patient samples. Among an all- 
male sample, Loewenstein and Putnam [36] reported $13 \%$ of patients reported having perpetrated a sexual assault, while in a predominately female sample, Putnam and colleagues [37] reported $20 \%$ of patients reported having perpetrated sexual assault. Lewis, Yeager, Swica, Pincus and Lewis [40] reported severe childhood maltreatment and adult psychopathology among 12 DID inmates who were incarcerated for homicide. Two studies found $19 \%$ of DID patients had completed homicide $[36,37]$. Loewenstein and Putnam [36] attribute this extremely high rate of violent behavior to the childhood maltreatment these patients experienced which increases their risk for aggression and violence, as well as their reliance on an all-male sample, who have higher rates of violence. Alternatively, Putnam and colleagues [37] describe confusion about "personified intraphysic conflicts" among the patients leading to misperceptions about the degree of actual violence among DID patients, as described above.

These numbers are concerning, but they are not consistent with more recent studies of DD patients and clinicians that utilize different sampling techniques and designs. Within the international prospective Treatment of Patients with DD (TOP DD) Network Study, only $2 \%$ of clinicians and $4-7 \%$ of patients report that DD (including both DID and DDNOS/OSDD) patients perpetrated sexual coercion or sexual assault toward a partner in their adult lifetime [41]. Additionally, rates of perpetration of intimate partner violence were low among DD patients, according to therapists: only $3.5 \%$ of DD patients were reported by their TOP DD therapists as having perpetrated physical or sexual abuse toward a partner in their adult lifetime [6].

To date, no studies have examined the variables that might contribute to violence and/or criminal behavior among individuals with DDs. Given the important role that emotion dysregulation has had in predicting violence among individuals with BPD, emotion dysregulation should be examined as a possible contributing factor among individuals with DDs. Dissociative and PTSD symptoms may also be associated with violence or criminal behavior due to the possibility that when highly symptomatic, individuals with DDs may be overwhelmed and unable to manage their symptoms such that they become vulnerable to dyscontrol. Lastly, potential psychological comordities to DDs related to violent behavior within the literature, such as mood and substance use disorders, should be examined as potential explanatorty variables for recent criminal justice involvement.

\section{The present study}

Many questions remain regarding what role mental illness plays in violence. Are mentally ill individuals more likely to perpetrate violence compared to people who do not have mental illness? What psychiatric diagnoses are most highly associated with violent behavior and crime? Are individuals with DDs particularly likely to engage in violent and/or criminal behavior? The present study attempts to provide evidence on violent behavior and crime among individuals with DDs engaged in outpatient treatment.

The purpose of our study was threefold; first, to provide a review of the extant literature on DDs and violent behavior; second, to describe the prevalence of recent criminal justice involvement among a sample of treatment-engaged individuals with DDs; and third, to assess symptomatic predictors of violent behavior and crime among individuals with DDs, including dissociative, emotion dysregulation, posttraumatic stress disorder (PTSD) and depressive symptoms, as well as problematic substance use. We hypothesized that crime rates would be low in our sample of individuals with DDs, with the majority of patients reporting no recent criminal history or involvement with the criminal justice system, unless their involvement was as victims of crime. Additionally, we hypothesized that the aforementioned symptoms (dissociation, emotion dysregulation, PTSD, depression and substance use) would not be significantly associated with recent criminal behavior and justice system involvement.

\section{Methods \\ Procedure \\ Overview and recruitment}

Clinician and patient participants were recruited through the Treatment of Patients with Dissociative Disorders (TOP DD) Network study. The TOP DD Network study is a longitudinal educational intervention study of patients with DDs who are diagnosed with either DID or DDNOS/OSDD. Over the course of 1 year, patients and clinicians watched weekly 7-15 min psychoeducational and skills training videos and completed written reflection and behavioral exercises. Additionally, therapist and patient participants completed surveys every 6 months (at baseline, 6, 12, 18 and 24 months) that provided additional clinical and behavioral data.

Clinicians were recruited through listservs for mental health professionals, professional trauma conferences and emails to participated in the first TOP DD study [42, 43]. Clinicians were asked to enroll as a dyad with one DD patient from their caseload. All clinician and patient participants completed a voluntary consent process, and the study was approved by the Towson University Institutional Review Board. Eligibility requirements for patients in the TOP DD Network study included a DD diagnosis (DID, DDNOS or OSDD); being in treatment with their current clinician for at least 3 months prior to starting the study; reading English at an $8^{\text {th }}$ grade level; 
being willing to continue in individual therapy and complete approximately $2 \frac{1}{2}$ hours weekly of study activities; and being able to tolerate references to trauma, dissociation and safety struggles.

\section{Participants}

The total TOP DD Network study included 242 patients who completed baseline measures, presented after the screening measures which verified study eligibility. TOP DD Network study patient participants were majority female (88.6\%), Caucasian (82.1\%), middle-aged (Median $=41)$, highly-educated $(50.9 \%$ had at least a college diploma), and primarily resided in the United States (42.3\%), although the study recruited internationally with a sizeable portion derived from Norway (27.5\%) as well as other countries (30.2\%). About half of participants (55.2\%) were either in a dating or married relationship. Patients were primarily diagnosed by their therapists as having DID (63.4\%). Clinician participants were primarily female $(80 \%)$ and Caucasian (91.3\%). Most reported years of experience as therapists (Median=15), as well as in treating trauma (Median =13), and dissociation (Median $=8$ ). Clinicians primarily worked in private practice $(81.1 \%)$ or in an outpatient clinic or hospital (41.6\%).

\section{Patient measures}

\section{Criminal justice involvement}

DD patients were asked about involvement with the criminal justice system in the last 6 months including contact with the police, charges, convictions, court cases, fines, incarceration, probation, referral to mental health through the criminal justice system, and serving as a criminal witness. Participants could respond yes or no to these questions. Clinicians were not asked about their patients' recent criminal justice involvement.

\section{Trait dissociation}

Trait dissociation was measured at baseline by the Dissociative Experiences Scale-II (DES) [28]. DES is a 28 -item, 10-point scale (ranging from 0 to $100 \%$ of the time) where the participant indicates what percentage of the time a particular dissociative experience occurred within the past month. A meta-analysis by van Ijzendoorn and Schuengel [44] demonstrated testretest reliability of .78-.93, $\alpha=.93$, and convergent validity of $r=.67$. The measure was scored by adding the item frequency values and dividing by the total number of items, yielding an average summary score for each participant.

\section{Emotion dysregulation}

Emotional dysregulation was measured at baseline by the Difficulties with Emotion Regulation Scale (DERS)
[45]. DERS is a 36-item, 5-point scale (ranging from almost never $[0-10 \%$ of the time] to almost always [91$100 \%$ of the time]) where the participant indicates what percentage of the time a particular difficulty with emotion regulation applies to them. The DERS has six subscales encompassing difficulties with accepting emotions, goal-directed behavior, impulse control, as well as lack of emotional awareness, emotional clarity and emotion regulation strategies. Gratz and Roemer [45] reported $\alpha>.80$ for the six DERS subscales, while Mitsopoulou, Kafetsios, Karademas, Papastefanakis \& Simos [46] demonstrated a test-retest reliability ranging from .63 to 81 for the six DERS subscales. The measure was scored by summing the item frequency values.

\section{Posttraumatic stress disorder}

PTSD symptomatology and severity was measured with PTSD Checklist-Civilian (PCL-C) [47]. The PCL-C is a 17-item, 5-point scale (ranging from not at all to extremely) where a participant indicates how often they have experienced a particular PTSD symptom within the past month. A total score of 50 points is the typical cutoff indicating a possible PTSD diagnosis [48]. Weathers and colleagues [47] reported a test-retest reliability of .96 with a retest interval of 2 to 3 days [47]. The measure was scored by summing all items together.

\section{Depression}

Depressive disorders were assessed by having clinicians report whether their patient currently had a diagnosis of either dysthymia or major depression (yielding answers of yes or no). Major depressive disorder and persistent depressive disorder (e.g., dysthymia) were assessed as potential predictors of criminal behavior.

\section{Substance use}

Substance use disorders were assessed by having clinicians report whether their patient currently had a diagnosis of a substance use disorder (differentiated from a substance/medication-induced mental disorder; answers were yes or no.)

\section{Analyses}

Binary logistic regression was utilized to assess symptomatic predictors of recent criminal justice involvement in individuals with DDs. Logistic regression was chosen because it predicts membership for a dichotomous dependent variable (i.e., criminal justice involvement) from multiple independent variables, and is appropriate in cases of unequal group sample sizes. We ran eight separate logistic regressions to assess symptomatic predictors of each of the eight criminal justice involvement variables. We report Nagelkerke $R$ squared effect sizes on the significant omnibus models. We adjusted alpha 
levels to account for multiple hypothesis testing, and the critical $p$-value $=0.0062$. The sample size for the logistic regression models was $N=125$, as variables were used from both clinician and patient surveys, and both prebaseline screening and baseline surveys, which each contained slightly different sample sizes.

\section{Results}

\section{Prevalence of recent criminal justice involvement}

Among 173 DD patients, 12.7\% reported contact with the police within the last 6 months; the reasons for this contact were not queried. The patients reported low rates of recent criminal behavior in the last 6 months (Table 6): 4.8\% reported involvement in a court case, although it is unknown what role the patient played in the court proceedings (e.g., witness, victim, alleged criminal); $3.6 \%$ were witnesses in a criminal case; $3 \%$ reported a legal charge; $1.8 \%$ reported a fine $(\mathrm{s}) ; 1.2 \%$ reported a criminal justice mental health referral; and $0.6 \%$ reported having been incarcerated. None of the 173 DD patients reported convictions or probation during the most recent 6 months.

Regarding the nature of criminal justice involvement, patients had the option of explaining criminal justice involvement they labeled as "other." Eight individuals elected to complete the "other" open text box, indicating the following: calling the non-emergency police due to loud neighbors; reporting a substance abusing child to the police; reporting criminal offenses; participating in divorce court and domestic violence orders; receiving a traffic ticket; "[meeting] with secret service;" reporting a suspicious vehicle; and being admitted to the hospital with police involvement.

\section{Symptomatic predictors of criminal justice involvement} Within binary logistic regressions assessing symptomatic predictors of eight types of recent criminal justice involvement, symptomatology significantly predicted recent contact with police, $\chi^{2}(6)=13.28, p<.05$, Nagelkerke $R^{2}=0.17$. Post-hoc tests indicated that only PTSD symptoms (via the PCL-C) significantly predicted recent contact with police, $p<.01$. However, after applying the critical $p$-value $=0.0062$, neither the omnibus model nor the post-hoc tests remained significant.

Symptomatology also significantly predicted recent contact with the court system, $X^{2}(6)=26.18, p<.001$, Nagelkerke $R^{2}=0.59$. Post-hoc tests indicated that PTSD symptoms (via the PCL-C) significantly predicted recent contact with the court system, $p<01$, as well as a substance use disorder diagnosis (via clinician report), $p<.01$. However, after applying the critical $p$-value $=$ 0.0062 , the post-hoc tests did not remain significant.

\section{Discussion}

The present study had three aims: first, to provide a review of the extant literature on DDs and violent behavior; second, to describe the prevalence of recent criminal justice involvement among a sample of treatmentengaged individuals with DDs; and third, to assess symptomatic predictors of recent criminal justice involvement within the DD sample.

As we hypothesized, criminal justice involvement among individuals with DDs within the prior 6 months was low, according to patient self-reports. Specifically, patients reported the following in the prior 6 months: $4.8 \%$ were involved in a court proceeding, $3.6 \%$ were witnesses in a criminal case, $3 \%$ had a legal charge, $1.8 \%$ received a fine (s), $1.2 \%$ received a criminal justice mental health referral, and only $0.6 \%$ had been incarcerated. None of the DD patients reported convictions or probation during the past 6 months. This contrasts with prior case study reviews of DID patients in which clinicians reported a history of violent behavior among $29-55 \%$ of DID patients, and severely violent crime (e.g., homicide and sexual assault) among upwards of $20 \%$ of patients [34, 36-38]. While the prior studies assess lifetime rates, as compared to the present study's 6-month time frame, and relied on clinician reports rather than patient selfreports, the inconsistencies are instructive. The contrasting results may mean that as sampling and assessment techniques develop, research on individuals with DDs will increasingly suggest they are not as prone to violence or crime as initially thought, as violence towards self may have been conflated with violence towards others. Individuals with DD seem to pose a greater threat to themselves then to anyone else, as reflected in their very high rates of self-injurious behavior and frequent suicide attempts [42, 43, 49].

Additionally, our hypothesis that symptoms of emotion dysregulation, dissociation, PTSD, depression (major depressive disorder and persistent depressive disorder), and substance use disorder were not associated with criminal justice involvement in our sample was supported. Out of eight different types of recent criminal justice involvement, symptoms were able to significantly predict only DD patients' recent contact with police, as well as recent court involvement, but the former omnibus model did not remain significant after applying the critical alpha which adjusted for Type I error due to multiple hypothesis testing. Regarding recent court involvement, PTSD symptoms and substsance use disorder symptoms significantly predicted recent court involvement, but again, these post-hoc tests did not remain significant after applying the critical alpha. Thus, no symptoms reliably predicted criminal behavior among those with DDs. More importantly, dissociative symptoms did not significantly predict any type of criminal 


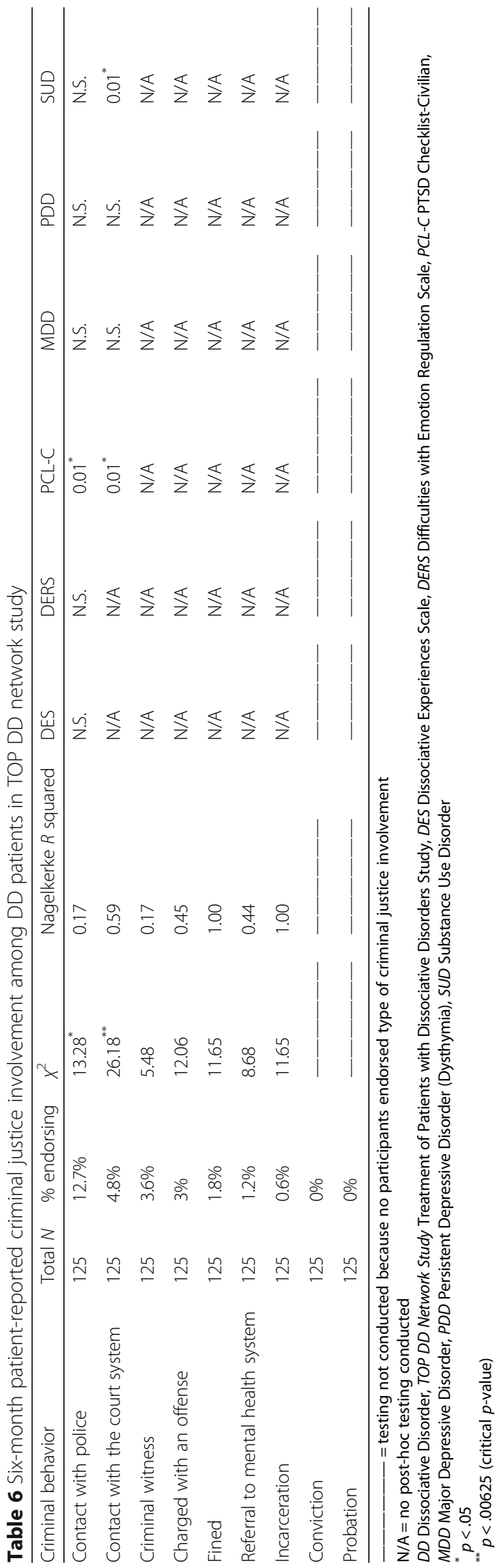


justice involvement among our sample of DD patients. This counters the notion that dissociative symptoms increase risk for criminal and violent behavior. It is also possible that given the high level of dissociation and PTSD among our sample, the strength of the relationships could have been attenuated due to a ceiling effect.

Our study's major limitations concern selection bias and the nature of data available on patients' criminal justice involvement. First, our participants are in psychotherapeutic treatment and thus may not be representative of those with DDs who do not present to treatment, nor of those in the criminal justice system who have DDs and dissociation. Additionally, by definition, our sample experience severe and chronic trait dissociation, but some criminal behavior may be more related to state dissociation [29, 30]. Second, our data on patients' criminal justice system involvement was limited: we did not collect clinician reports of patients' recent criminal justice involvement, details regarding the nature of patients' recent criminal justice involvement (i.e., our data on police contact and court cases are ambiguous as to whether they indicate possible criminal behavior or being involved as a witness or victim), nor data on lifetime criminal justice involvement. Many studies on mental illness and violent behavior use lifetime rates, and thus this would facilitate comparisons across studies.

Using patient self-reports of criminal justice involvement in the present study may have provided more accurate responses than only using clinician reports, as it is possible that patients would not report criminal behavior to their clinicians due to social desirability concerns and taboos around criminality, although clinician reports would have been a useful adjunct to patient self-reports. Future studies should review criminal justice records for this population because lifetime memories can be difficult to accurately solicit due to amnesia, and due to the confusion some patients may experience between past and present as well as internal versus external events [39]. Future studies should assess both lifetime and recent criminal justice involvement, utilizing clinician reports and criminal justice records in addition to patient self-reports.

Studies on psychopathology and violent behavior should include DD individuals in their samples. Small forensic studies have assessed DDs in violent offenders [40] but larger epidemiological studies of violent offenders have not included DDs, despite assessing a range of psychopathology among offenders $[7-9,11-14,26,27]$.

\section{Conclusions}

In summary, recent criminal justice involvement among our DD clinical sample is low, according to patient selfreports and is not predicted by dissociative, PTSD or emotion dysregulation symptoms, nor by clinician reported substance abuse disorders or mood disorders. This provides compelling evidence contradicting public and media misconceptions and stereotypes of those with DDs as highly prone to criminality and violence. Public awareness about DDs needs to improve through thoughtful and accurate portrayals of DD, as well as all mental illnesses, in media and literature so that stereotypes and stigma are replaced with understanding and scientifically based knowledge. Enduring stigmas portraying those with mental illness as violent may have considerable negative impacts on their treatment engagement, ability to seek out social support, and overall quality of life $[2,3]$. Reductions in stereotypes and stigma will allow those with mental illness to live more comfortably and safely and allow the general public to also be less fearful and more compassionate towards those with DDs and all forms of mental illness.

\section{Endnotes}

${ }^{1}$ Sometimes referred to as personalities, identities or parts.

\section{Abbreviations}

BPD: Borderline personality disorder; DD: Dissociative disorders; DDNOS: Dissociative disorder not otherwise specified; DERS: Difficulties with Emotion Regulation Scale; DES: Dissociative Experiences Scale; DID: Dissociative identity disorder; DSM: Diagnostic and Statistical Manual of Mental Disorders; OSDD: Other specified dissociative disorder; PCL-C: PTSD Checklist-Civilian; PTSD: Posttraumatic stress disorder; SMI: Severe mental illness; TOP DD Network Study: Treatment of Patients with Dissociative Disorders Network Study

\section{Acknowledgements \\ The authors warmly thank the patients and therapists who generously donated their time to participate in the TOP DD Network study.}

\section{Funding}

The authors declare that this research was funded by foundations (i.e., ANS Research, Constantinidas Family Foundation), private donations (including from Anne Bartello and family, Brad Foote, M.D. and gifts made to Sheppard Pratt Health System's Trauma Disorders Research Program and Towson University's Foundation), and grants from Towson University.

\section{Availability of data and materials}

Please contact corresponding author for data requests.

\section{Authors' contributions}

ARW conducted the literature review, analyzed the data and drafted the manuscript. BLB is the Principal Investigator for the study from which the data is derived (the TOP DD Network Study), developed the methods and assisted in manuscript writing. Both authors read and approved the final manuscript.

\section{Authors' information}

Aliya R. Webermann, M.A., is a clinical/community doctoral student at University of Maryland, Baltimore County (UMBC), USA and a graduate of the clinical psychology master's program at Towson University. Ms. Webermann's research primarily concerns the links between intimate partner violence, complex trauma and trauma and dissociative disorders. Bethany L. Brand, Ph.D., is the Martha A. Mitten Professor of Psychology at Towson University and maintains an independent practice in clinical psychology on Towson, Maryland, USA. She serves as an expert witness in criminal, civil, disability and employment matters. Dr. Brand conducts research on the assessment and treatment of trauma disorders, including the assessment of feigned dissociative disorders. 


\section{Competing interests}

The authors declare that they have no competing interests.

\section{Consent for publication}

Not applicable.

\section{Ethics approval and consent to participate}

The TOP DD Network Study received approval from the Towson University Institutional Review Board in 2014, IRB number IRB00002844. All particpants completed an informed consent process before participating in the study.

\section{Author details}

'University of Maryland Baltimore County, 1000 Hilltop Circle, Math/ Psychology Building Rm. 312, Baltimore County, Baltimore, MD 21250, USA. ${ }^{2}$ Department of Psychology, Towson University, Towson 21252, MD, USA.

Received: 30 October 2016 Accepted: 13 January 2017

Published online: 23 January 2017

\section{References}

1. Link BG, Phelan JC, Bresnahan M, Stueve A, Pescosolido BA. Public conceptions of mental illness: Labels, causes, dangerousness, and social distance. Am J Public Health. 1999;89(9):1328-33.

2. Gonzales L, Davidoff KC, Nadal KL, Yanos PT. Microaggressions experienced by persons with mental illnesses: An exploratory study. Psychiatr Rehabil J. 2015;38(3):234-41.

3. Stuart H. Media portrayal of mental illness and its treatments: What effect does it have on people with mental illness? CNS Drugs. 2006;20(2):99-106.

4. Crisanti AS, Frueh BC, Archambeau O, Steffen JJ, Wolff N. Prevalence and correlates of criminal victimization among new admissions to outpatient mental health services in Hawaii. Community Ment Health J. 2014;50(3):296-304.

5. Teplin LA, McClelland GM, Abram KM, Weiner DA. Crime victimization in adults with severe mental IIIness: Comparison with the National Crime Victimization Survey. Arch Gen Psychiatry. 2005;62(8):911-21.

6. Webermann AR, Brand BL, Chasson GS. Childhood maltreatment and intimate partner violence in dissociative disorder patients. Eur J Psychotraumatol. 2014;5:1-8

7. Elbogen EB, Johnson SC. The intricate link between violence and menta disorder: Results from the national epidemiologic survey on alcohol and related conditions. Arch Gen Psychiatry. 2009;66(2):152-61.

8. Fazel S, Grann M. Psychiatric morbidity among homicide offenders: A Swedish population study. Am J Psychiatry. 2004;161(11):2129-31.

9. Flynn S, Abel KM, While D, Mehta H, Shaw J. Mental illness, gender and homicide: A population-based descriptive study. Psychiatry Res. 2011;185(3): 368-75

10. González RA, Igoumenou A, Kallis C, Coid JW. Borderline personality disorder and violence in the UK population: Categorical and dimensional trait assessment. BMC Psychiatry. 2016;16:1-10.

11. Swanson JW, Holzer CE, Ganju VK, Jono RT. Violence and psychiatric disorder in the community: Evidence from the Epidemiologic Catchment Area surveys. Hosp Community Psychiatry. 1990;41(7):761-70

12. Coker KL, Smith PH, Westphal A, Zonana HV, McKee SA. Crime and psychiatric disorders among youth in the US population: An analysis of the national comorbidity survey-adolescent supplement. J Am Acad Child Adolesc Psychiatry. 2014;53(8):888-98.

13. Rodway C, Flynn S, While D, Rahman MS, Kapur N, Appleby L, Shaw J. Patients with mental illness as victims of homicide: A national consecutive case series. Lancet Psychiatry. 2014;1(2):129-34.

14. Simpson AF, McKenna B, Moskowitz A, Skipworth J, Barry-Walsh J. Homicide and mental illness in New Zealand, 1970-2000. British J Psychiatry. 2004; 185(5):394-8.

15. Behavioral health trends in the United States: Results from the 2014 National Survey on Drug Use and Health (HHS Publication No. SMA 154927, NSDUH Series H-50). Center for Behavioral Health Statistics and Quality. 2015. https://www.samhsa.gov/data/sites/default/files/NSDUH-FRR12014/NSDUH-FRR1-2014.pdf. Retrieved 3 Aug 2016.

16. Gourion D. Schizophrenia and violence: A common developmental pathway? In: Verrity PM, editor. Violence and aggression around the globe. Hauppauge: Nova; 2007. p. 29-44.
17. Swanson JW, Borum R, Swartz MS, Monahan J. Psychotic symptoms and disorders and the risk of violent behaviour in the community. Crim Behav Ment Health. 1996;6(4):309-29.

18. Walsh E, Gilvarry C, Samele C, Harvey K, Manley C, Tattan T, Tyrer P, Creed F, Murray R, Fahy T. Predicting violence in schizophrenia: A prospective study. Schizophr Res. 2004;67(2-3):247-52.

19. Newhill CE, Eack S, Mulvey EP. A growth curve analysis of emotion dysregulation as a mediator for violence in individuals with and without borderline personality disorder. J Pers Disord. 2012;26(3):452-67.

20. Scott LN, Stepp SD, Pilkonis PA. Prospective associations between features of borderline personality disorder, emotion dysregulation, and aggression. Pers Disord. 2014;5(3):278-88.

21. Brand BL, Lanius RA. Chronic complex dissociative disorders and borderline personality disorder: Disorders of emotion dysregulation? Borderline Personal Disord Emot Dysregul. 2014;1:13.

22. Bruce M, Cobb D, Clisby H, Ndegwa D, Hodgins S. Violence and crime among male inpatients with severe mental illness: Attempting to explain ethnic differences. Soc Psychiatry Psychiatr Epidemiol. 2014;49(4):549-58.

23. Hodgins S, Alderton J, Cree A, Aboud A, Mak T. Aggressive behaviour, victimisation and crime among severely mentally ill patients requiring hospitalisation. British J Psychiatry. 2007:191(4):343-50.

24. Matejkowski JC, Cullen SW, Solomon PL. Characteristics of persons with severe mental illness who have been incarcerated for murder. J Am Acad Psychiatry Law. 2008;36(1):74-86.

25. Jordan B, Schlenger WE, Fairbank JA, Caddell JM. Prevalence of psychiatric disorders among incarcerated women: Convicted felons entering prison. Arch Gen Psychiatry. 1996;53(6):513-9.

26. Crime in the United States, 2014. United States Department of Justice, Federal Bureau of Investigation.2015. https://ucr.fbi.gov/crime-in-the-u.s/ 2014/crime-in-the-u.s.-2014/cius-home. Retrieved 3 Aug 2016.

27. Wilcox DE. The relationship of mental illness to homicide. Am J Forensic Psychiatry. 1985;6(1):3-15.

28. Carlson EB, Putnam FW. An update on the Dissociative Experiences Scale. Dissociation. 1993;6(1):16-27.

29. Kruger C, Mace CJ. Psychometric validation of the State Scale of Dissociation (SSD). Psychol Psychother Theory Res Pract. 2002;75:33-51.

30. Moskowitz A. Dissociation and violence: A review of the literature. Trauma Violence Abuse. 2004;5(1):21-46.

31. Quimby LG, Putnam FW. Dissociative symptoms and aggression in a state mental hospital. Diss. 1991;4(1):21-4.

32. Kaplan ML, Erensaft M, Sanderson WC, Wetzler S, Foote B, Asnis GM. Dissociative symptomatology and aggressive behavior. Compr Psychiatry. 1998;39(5):271-6.

33. Egeland B, Susman-Stillman A. Dissociation as a mediator of child abuse across generations. Child Abuse Negl. 1996;20(11):1123-32

34. Dell PF, Eisenhower JW. Adolescent multiple personality disorder: A preliminary study of eleven cases. J Am Acad Child Adolesc Psychiatry. 1990;29(3):359-66.

35. Kluft RP. The parental fitness of mothers with multiple personality disorder: A preliminary study. Child Abuse Negl. 1987;11(2):273-80

36. Loewenstein RJ, Putnam FW. The clinical phenomenology of males with MPD: A report of 21 cases. Dissociation. 1990;3(3):135-43.

37. Putnam FW, Guroff JJ, Silberman EK, Barban L, Post RM. Clinical phenomenology of multiple personality disorder: review of 100 recent cases. J Clin Psychiatry. 1986:47(6):285-93.

38. Ross CA, Norton GR. Differences between men and women with multiple personality disorder. Hosp Community Psychiatry. 1989:40(2):186-8.

39. International Society for the Study of Trauma and Dissociation. Guidelines for treating dissociative identity disorder in adults, third revision. J Trauma Dissociation. 2011;12(2):115-87.

40. Lewis $D$, Yeager CA, Swica Y, Pincus JH, Lewis M. Objective documentation of child abuse and dissociation in 12 murderers with dissociative identity disorder. Am J Psychiatry. 1997;154(12):1703-10.

41. Webermann AR, Brand BL. The sitting duck syndrome: What contributes to dissociative patients' being victims and perpetrators of violence? Symposium to be presented to the 33rd Annual International Society for the Study of Trauma and Dissociation (ISSTD) Conference. 2016.

42. Brand BL, Classen C, Lanius R, Loewenstein R, McNary S, Pain C, Putnam FW. A naturalistic study of dissociative identity disorder and dissociative disorder not otherwise specified patients treated by community clinicians. Psychol Trauma. 2009;1(2):153-71. 
43. Brand BL, McNary SW, Myrick AC, Classen CC, Lanius R, Loewenstein RJ, Pain C, Putnam FW. A longitudinal naturalistic study of patients with dissociative disorders treated by community clinicians. Psychol Trauma. 2013;5(4):301-8.

44. van ljzendoorn MH, Schuengel C. The measurement of dissociation in normal and clinical populations: Meta-analytic validation of the Dissociative Experiences Scale (DES). Clin Psychol Rev. 1996;16(5):365-82.

45. Gratz KL, Roemer L. Multidimensional assessment of emotion regulation and dysregulation: Development, factor structure, and initial validation of the difficulties in emotion regulation scale. J Psychopathol Behav Assess. 2004; 26(1):41-54.

46. Mitsopoulou E, Kafetsios K, Karademas E, Papastefanakis E, Simos PG. The Greek version of the Difficulties in Emotion Regulation Scale: Testing the factor structure, reliability and validity in an adult community sample. J Psychopathol Behav Assess. 2013;35(1):123-31.

47. Weathers FW, Litz BT, Huska JA, Keane TM. The PTSD Checklist—Civilian Version (PCL-C). Boston: National Center for PTSD; 1994.

48. Weathers FW, Ford J. Psychometric review of PTSD Checklist. In: Stamm BH, editor. Measurement of stress, trauma, and adaptation. Lutherville: Sidran Press; 1996. p. 250-1.

49. Webermann AR, Myrick AC, Taylor CL, Chasson GS, Brand BL. Dissociative, depressive, and PTSD severity as correlates of non-suicidal self-injury and suicidality in dissociative disorder patients. J Trauma Dissociation. 2016;17(1): 67-80.

\section{Submit your next manuscript to BioMed Central and we will help you at every step:}

- We accept pre-submission inquiries

- Our selector tool helps you to find the most relevant journal

- We provide round the clock customer support

- Convenient online submission

- Thorough peer review

- Inclusion in PubMed and all major indexing services

- Maximum visibility for your research

Submit your manuscript at www.biomedcentral.com/submit

) Biomed Central 